\title{
Problematika Implementasi Kurikulum 2013 dalam Pembelajaran Akidah Akhlak di Madrasah Tsanawiyah Kota Prabumulih
}

\author{
Sunardi $^{*}$, Abdurrahmansyah ${ }^{2}$ \\ ${ }^{1 *}$ MTs Al-Furqon, Prabumulih, Indonesia \\ sunardi.1407@gmail.com \\ ${ }^{2}$ Universitas Islam Negeri Raden Fatah, Palembang, Indonesia \\ Abdurrahmansyah uin@radenfatah.ac.id
}

\begin{tabular}{|c|c|}
\hline \multicolumn{2}{|c|}{ ABSTRACT } \\
\hline \multicolumn{2}{|c|}{$\begin{array}{l}\text { This study aims to determine the Problems in the Implementation of the } 2013 \text { Curriculum, starting } \\
\text { from the design, implementation, and evaluation in MTs Prabumuli, then the factors underlying } \\
\text { these problems, as well as the efforts made by teachers in overcoming the problems of implementing } \\
\text { the } 2013 \text { Curriculum. The research approach used is a qualitative approach. While this type of } \\
\text { research is field research. Sources of research data are the headmaster of the madrasah, deputy head } \\
\text { of curriculum and teachers of the Akidah Akhlak. Data collection method is done by observation, } \\
\text { interview and documentation. Data processing methods in this study were obtained through research } \\
\text { instruments, through four stages, namely data reduction, data presentation, data verification and } \\
\text { triangulation. The results of this study indicate that: First, the problems in implementing the } 2013 \\
\text { curriculum in the learning of the Morals in the VII grade of MTs Prabumulih such as, 1) In planning, } \\
\text { the making of a learning plan is not in accordance with the provisions, especially in the composition } \\
\text { of the RPP and writing material, 2) In the implementation, the implementation of learning does not } \\
\text { use the lesson plan as the basis of the learning flow, many learning steps that have not been done, } \\
\text { the characteristics of the 2013 curriculum have not been fully implemented, 3) In evaluation, } \\
\text { evaluation is still considered difficult and burdensome for teachers so that some aspects of } \\
\text { assessment such as attitude and skills assessment are not carried out in accordance with the } \\
\text { provisions. Second, from the above problems the factors are: 1) The lack of teacher's understanding } \\
\text { of the 2013 curriculum concept from all aspects, 2) The teacher still considers that the } 2013 \\
\text { curriculum is very burdensome, 3) The lack of teacher awareness in the implementation of the } 2013 \\
\text { curriculum, 4) Low morale and work ethic for teachers. Third, some of the efforts made by the } \\
\text { Akidah Akhlak teachers in overcoming existing problems such as: 1) Teachers seeking information } \\
\text { about the 2013 curriculum concept independently, 2) Teachers play an active role in MGMP } \\
\text { activities, 3) Collaboration with more senior teachers in the implementation of } 2013 \text { curriculum. }\end{array}$} \\
\hline \multicolumn{2}{|l|}{ Keywords : Curriculum 2013, Learning of Mor } \\
\hline & \\
\hline & \\
\hline
\end{tabular}




\section{PENDAHULUAN}

Sejak kemerdekaan 1945, Indonesia telah mengalami sebelas kali perubahan kurikulum. Perubahan kurikulum, antara lain, bertujuan untuk menyesuaikan kurikulum pendidikan dengan perkembangan masyarakat, ilmu pengetahuan dan teknologi (Ahmad, 2014). Perubahan kurikulum merupakan suatu keniscayaan. Pemerintah lewat Kementrian Pendidikan dan Kebudayaan (Kemdikbud), telah melaksanakan perubahan kurikulum mulai tahun pelajaran 2013/2014. Seperti yang dikemukakan oleh Kemdikbud, KTSP diubah dengan Kurikulum 2013, tepatnya pada bulan Juli 2013 yang diberlakukan secara bertahap di sekolah. Kurikulum 2013 ini juga tidak lepas dari pro dan kontra dari seluruh masyarakat Indonesia karena menimbulkan beberapa masalah. Kurikulum 2013 mendapat sorotan dari berbagai pihak. "Meskipun demikian Mendikbud M. Nuh pada waktu itu sangat optimis dengan kurikulum ini, bahkan dengan semangat yang menggebu-gebu dengan ungkapan "Kurikulum 2013 harus jalan" (Mulyasa, 2014). Kurang optimalnya sosialisasi kepada seluruh pelaksana di lapangan membuat para guru masih banyak yang kebingungan terhadap kurikulum 2013. Pemerintah menganggap kurikulum ini lebih berat dari pada kurikulum-kurikulum sebelumnya. Guru sebagai ujung tombak implementasi Kurikulum 2013, sedangkan guru yang tidak profesional hanya dilatih beberapa bulan saja untuk mengubah pembelajaran sesuai dengan Kurikulum 2013. Selain penguatan dan pendampingan terhadap guru. siswa juga membutuhkan penguatan dan pendampingan dalam mengembangkan sikap dan karakter siswa yang ditekankan dalam Kurikulum 2013. Diharapkan dengan penerapan kurikulum 2013 adanya "perubahan perilaku hasil belajar bersifat efektif”, artinya sesuai dengan yang diharapkan (Normatif).

Selain itu pemerintah juga berencana menambah jam pelajaran agar pembelajaran lebih mengedepankan karakter siswa (Poerwati, 2013). Terkait dengan kurikulum 2013 Muhammad Nuh sebagai menteri pendidikan pada waktu itu menegaskan, bahwa kurikulum 2013 dirancang sebagai upaya mempersiapkan generasi Indonesia 2045 yaitu tepatnya 100 tahun Indonesia merdeka, sekaligus memanfaatkan populasi usia produktif yang jumlahnya sangat melimpah agar menjadi bonus demografi dan tidak menjadi bencana demografi. Namun dengan banyaknya lembaga, organisasi maupun perseorangan yang terlibat dalam perubahan Kurikulum 2013 ini, belum ada jaminan bahwa Kurikulum tersebut mampu membawa bangsa dan negara ini ke arah kemajuan. Pola pembelajaran baru di sekolah menggunakan kurikulum 2013 merubah model pembelajaran dari terpusat kepada guru (teacher centered learning) menjadi terpusat kepada siswa (student centered learning). Jadi guru yang pada awalnya sebagai sumber informasi utama bagi siswa sekarang siswa yang dituntut aktif untuk mencari informasi terlebih dahulu. Dengan perkembangan teknologi yang sangat pesat, siswa dapat memperoleh sumber belajar dengan sangat mudah, akses internet dan kecanggihan teknologi mendominasi perkembangan siswa untuk aktif mencari informasi. Pada dasarnya teknologi dan informasi menjadi sarana wajib dalam pembelajaran kurikulum 2013 yang di terapkan pada saat proses pembelajaran. Kurikulum harus mampu membekali peserta didik dengan berbagai kompetensi. Kompetensi yang diperlukan di masa depan sesuai dengan perkembangan global, antara lain: kemampuan berkomunikasi, kemampuan berpikir jernih dan kritis, kemampuan mempertimbangkan segi mental suatu permasalahan, kemampuan menjadi warga negara yang bertanggung jawab, kemampuan mencoba untuk mengerti dan toleran terhadap pandangan yang berbeda, kemampuan hidup dalam masyarakat yang mengglobal, memiliki minat luas dalam kehidupan, memiliki kesiapan untuk bekerja, memiliki kecerdasan dengan bakat atau minatnya, dan memiliki rasa tanggung jawab terhadap lingkungan.

Untuk mencapai tujuan tersebut menuntut perubahan pada berbagai aspek lain, terutama dalam implementasinya dilapangan. Pada proses pembelajaran, dari siswa "diberi tahu" menjadi siswa "mencari tahu", sedangkan proses penilaian dari berfokus pada pengetahuan melalui penilaian output menjadi berbasis kemampuan melalui penilaian proses, fortopolio dan 
penilaian output secara utuh dan menyeluruh. Oleh karena hal itu pengembangan kurikulum 2013 nantinya akan menghasilkan peserta didik yang produktif, kreatif, inovatif, afektif; melalui penguatan sikap, keterampilan, dan pengetahuan yang terintegrasi. Dalam tahap implementasi kurikulum 2013 di lapangan, tentu memiliki tahapan-tahapan, dimulai dari perencanaan yang matang, baik para guru maupun pasilitas pendukung, kemudian implementasinya dalam pembelajaran yang merupakan ujung tombak penentu keberhasilan dalam implementasi kurikulum 2013, serta dengan melakukan evaluasi yang baik, sehingga pada akhirnya dapat dilihat hasilnya. Tahapan-tahapan tentunya harus dilaksanakan dengan baik, jika ada tahapan yang dilalui tidak sesuai dengan aturan yang ada, maka bisa dipastikan hasil yang dicapaipun tidak akan maksimal.

Seluruh Madrasah Tsanawiyah di kota Prabumulih yang berjumlah enam madrasah dan semuanya telah melaksanakan kurikulum 2013. Pelaksanaan kurikulum 2013 mengacu pada ketentuan pemerintah melalui keputusan Direktur Jendral Pendidikan Islam Nomor 3525 tahun 2017 tentang Penetapan Madrasah Pelaksana Kurikulum 2013 yang telah mewajibkan kepada seluruh Madrasah untuk menyelenggarakan Kurikulum 2013 secara penuh.

Berdasarkan hasil interview dan Observasi awal peneliti di beberapa Madrasah Tsanawiyah Kota Prabumulih, semua madrasah telah penerapan kurikulum 2013 sudah mencakup seluruh mata pelajaran, baik mata pelajaran rumpun PAI maupun mata pelajaran umum, namun dalam implementasinya khususnya dalam pembelajaran Akidah Akhlak, peneliti masih menemukan para guru yang mengajar belum sesuai dengan ketentuan yang di atur dalam kurikulum 2013, di antaranya guru belum menggunakan pendekatan saintifik dalam pembelajaran, pendekatan saintifik merupakan ciri khas dalam kurikulum 2013. Guru dalam mengajar juga masih menggunakan model pembelajaran terpusat pada guru (teacher center learning), artinya kelas masih didominasi oleh guru sebagai sumber utama informasi dan siswa hanya menerima saja. Semestinya dalam kurikulum 2013 siswa dituntut untuk aktif mencari informasi pelajaran. Dan pembelajaran menggunakan pola yang berpusat pada siswa (student center learning) bukan pada guru (teacher center learning).

\section{METODOLOGI}

Penelitian ini penulis menggunakan teknik analisis data menggunakan teori Miles dan Hubermen yaitu melalui data reduction (reduksi data), data display (penyajian data), dan consclusion drawing/verification (kesimpulan), secara interaktif dan berlangsung secara terus menerus sampai tuntas, sehingga datanya sampai jenuh (Sugiyono, 2014). Penelitian ini merupakan penelitian kualitatif dengan teknik pengumpulan data observasi, wawancara dan studi dokumentasi. Sumber data utama dalam penelitian ini adalah guru-guru Akidah Akhlak yang ada di kelas VII Madrasah Tsanawiyah yang dipilih secara purposive di Kota Prabumulih. Data dianalisis melalui reduksi data, penyajian data, dan membuat kesimpulan. Pemeriksaan keabsahan data dilakukan dengan cara triangulasi, baik itu trianggulasi teknik maupun trianggulasi sumber dan meningkatkan ketekunan peneliti

\section{HASIL DAN PEMBAHASAN}

Dalam penelitian ini ada tiga pokok pembahasan yang menjadi fokus penelitian, yaitu Problematika yang dihadapi guru dalam Implementasi Kurikulum 2013 pada pembelajaran Akidah Akhlak, setelah itu akan diuraikan tentang faktor penyebab munculnya problematika Implementasi Kurikulum 2013 pada pembelajaran Akidah Akhlak serta pada akhirnya akan di bahas juga tentang upaya yang dilakukan guru Madrasah Tsanawiyah di kota Prabumulih dalam mengatasi problematika implementasi Kurikulum 2013 pada pembelajaran Akidah Akhlak.

Perubahan kurikulum merupakan akibat dari perkembangan masyarakat. kita tidak ingin membangun generasi yang terpisah dengan masyarakat. Kita mendidik generasi yang akan 
hidup di zaman yang berbeda dengan kita. Untuk menyukseskan implementasi kurikulum 2013 harus dimulai dengan peningkatan kualitas guru, yang sampai saat ini masih banyak kendala dan tantangan yang dihadapi, terutama dalam pelaksanaan pembelajaran. Hal ini penting karena kunci keberhasilan dalam implementasi kurikulum pembelajaran adalah kemampuan profesional guru. Dalam kaitanya dengan implementasi kurikulum 2013, tentu akan ditemukan banyak permasalahan-permasalahan dalam implementasinya. Menurut Yani (2013) permasalahan yang utama dalam implementasi kurikulum 2013 adalah "merubah Mindset guru dalam mengajar" dari mindset kurikulum KTSP berubah ke mindset kurikulum 2013, diantaranya perubahan proses pembelajaran dari teacher centered ke student centered, pembelajaran menggunakan pendekatan saintifik dan penilaian autentik. Selanjutnya guru masih terbiasa dengan cara mengajar yang lama, yang lebih menekankan pada aspek Kognitif (Yani, 2013).

Problem selanjutnya yang mungkin akan dihadapi guru menurut Arifin (2017), adalah masih kurangnya sikap dan kemampuan guru berfikir kritis, analitis, reflektif, konstruktif, dan antisipatif terhadap kurikulum yang dikenalkan. Kemungkinan lain yaitu kemampuan guru yang bervariasi dalam memahami konsep kurikulum 2013, menyebabkan pemahaman, sikap dan kemampuan mengimplementasikan kurikulum juga kurang bervariasi (Arifin, 2017).

Implementasi adalah suatu proses penerapan ide, konsep, kebijakan atau inovasi dalam suatu tindakan praktis sehingga memberikan dampak baik berupa perubahan pengetahuan, keterampilan, maupun nilai dan sikap. Implementasi kurikulum dapat diartikan sebagai aktualisasi kurikulum tertulis dalam bentuk pembelajaran. Implementasi kurikulum adalah penerapan atau pelaksanaan program kurikulum yang telah dikembangkan dalam tahap sebelumnya, kemudian diujicoba dengan pelaksanaan dan pengelolaan, dan juga senantiasa dilakukan penyesuaian terhadap situasi lapangan (Kunandar, 2007).

Dalam mengimplementasikan Kurikulum 2013, setidaknya ada beberapa tahapan yang harus dilakukan oleh seorang pendidik, tahapan-tahapan tersebut diantaranya: Pertama; Implementasi Kurikulum 2013 pada tahap Perencanaan, Kedua; Implementasi Kurikulum pada tahap pelaksanaan dalam pembelajaran dan Ketiga; Implementasi Kurikulum pada tahap penilaian hasil belajar. Selanjutnya akan dibahas masing-masing dari tahapan tersebut berdasarkan hasil temuan penelitian di lapangan.

\section{Uraian Data Implementasi Kurikulum 2013 Pada Pembelajaran Akidah Akhlak di MTs Kota Prabumulih}

Setiap pekerjaan harus direncanakan terlebih dahulu agar segalanya berjalan lebih maksimal. Begitu pula dalam suatu pembelajaran. Terkait tahap perencanaan pembelajaran, madrasah haruslah memfasilitasi para guru dalam membuat perangkat pembelajaran, karena guru merupakan ujung tombak dalam pengimplementasian kurikulum 2013. Pembelajaran adalah proses interaksi peserta didik dengan pendidik dan sumber belajar pada satu lingkungan belajar. Dalam penelitian ini secara implisit dalam pembelajaran, terdapat pembelajaran memilih, menetapkan, mengembangkan metode untuk mencapai hasil pengajaran yang diinginkan (Uno, 2006). Oleh karena itu, di awal pemberitahuan tentang perubahan kurikulum 2013 di MTs Kota Prabumulih, rata-rata madrasah telah mengirim perwakilan untuk mengikuti kegiatan pelatihan Bimtek Kurikulum 2013.

Setelah serangkaian pelatihan dan sosialisasi kurikulum 2013 dilakukan, barulah para guru merencanakan pembelajaran yang sesuai dengan kurikulum 2013. Rencana pembelajaran sangat penting bagi guru, karena dengan adanya rencana pembelajaran, guru bisa fokus pada materi yang telah siapkan. Untuk menganalisis rencana pembelajaran maka peneliti melihat perangkat pembelajaran yang dibuat oleh guru Akidah Akhlak khususnya pada Rancangan Pelaksanaan Pembelajaran (RPP) di kelas VII. Penyusunan RPP tersebut merupakan suatu bukti 
implementasi kurikulum 2013 tahap perencanaan. RPP dibuat oleh masing-masing guru, sesuai dengan hasil wawancara peneliti terhadap Guru Akidah Akhlak. Dalam pembuatan RPP diserahkan ke masing-masing guru karena RPP merupakan panduan masing-masing guru dalam mengajar, satu sama lain tentu berbeda cara mengajarnya.

Data tersebut diperkuat dengan hasil dokumentasi. Peneliti menerima secara langsung RPP dari guru Akidah Akhlak dari keempat madrasah tersebut, ini bukti bahwa guru telah membuat rencana pembelajaran. Kemudian, berkaitan dengan waktu pembuatan RPP, berdasarkan pengakuan dari seluruh guru Akidah Akhlak dari Empat Madrasah yaitu Guru Akidah Akhlak MTs Negeri (GAA.N), Guru Akidah Akhlak MTs Negeri MTS Al-Furqon (GAA.AF), Guru Akidah Akhlak MTs Amal Bakti (GAA.AB) dan Guru Akidah Akhlak MTs Darusaalam (GAA.DS) bahwa pembuatan RPP dilakukan di awal semester beserta perangkat pembelajaran yang lain.

Untuk selanjutnya, berdasarkan hasil telaah RPP, akan peneliti paparkan khusus pada poin komponen kurikulum, seperti Tujuan, Materi, metode dan evaluasi sebagai berikut:

\section{Tujuan Pembelajaran}

Tujuan pembelajaran merupakan arah sasaran dari kegiatan pembelajaran. Tujuan pembelajaran menggambarkan apa yang ingin dicapai dari kegiatan tersebut. Tujuan pembelajaran ditulis menggunakan kata kerja operasional yang dapat diamati dan diukur, yang mencakup sikap, pengetahuan, dan keterampilan. Ada beberapa komponen yang harus diperhatikan di dalam menyusun tujuan pembelajaran, antara lain: Audience (pendengar), Behavior (tingkah laku atau aktivitas suatu proses), Condition (kondisi diartikan sebagai suatu keadaan) dan Degree (suatu perbandingan).

Dari hasil dokumentasi rencana pembelajaran GAA.N, dapat peneliti tulis tujuan pembelajaran yang dibuat GAA.N adalah setelah melakukan kegiatan pembelajaran diharapkan peserta didik dapat meyakini sifat-sifat wajib dan sifat-sifat mustahil bagi Allah, dan dapat mengidentifikasi sifat-sifat wajib serta sifat-sifat mustahil bagi Allah beserta bukti/dalil naqli dan aqli-nya.

Dalam RPP GAA.AF, tujuan pembelajarannya adalah setelah melakukan kegiatan pembelajaran diharapkan peserta didik dapat menghayati kisah keteladanan Nabi Sulaiman dan umatnya, setelah melakukan kegiatan pembelajaran diharapkan peserta didik dapat mencontoh kisah keteladanan Nabi Sulaiman dan umatnya, dan setelah melakukan kegiatan pembelajaran diharapkan peserta didik dapat menganalisis kisah keteladanan Nabi Sulaiman dan umatnya.

Sedangkan dalam RPP GAA.AB, juga telah menuliskan tujuan pembelajarannya adalah setelah melakukan kegiatan pembelajaran diharapkan peserta didik dapat menampilkan perilaku mengimani sifat-sifat Allah, dan setelah melakukan kegiatan pembelajaran diharapkan peserta didik dapat menyajikan contoh fenomena-fenomena kehidupan yang muncul sebagai bukti dari sifat wajib, mustahil, dan jaiz Allah SWT.

Selanjutnya GAA.DS menuliskan tujuan pembelajarannya adalah Setelah peserta didik mengamati, menanya, mengeksplorasi, menalar, dan merefleksi tentang sifat-sifat Allah diharapkan mampu meyakini sifat-sifat wajib Allah yang nafsiyah, salbiyah, ma'ani, dan ma'nawiyah, sifat-sifat mustahil, serta sifat ja'iz Allah, dan setelah peserta didik mengamati, menanya, mengeksplorasi, menalar, dan merefleksi tentang sifat-sifat Allah diharapkan mampu menampilkan perilaku orang yang mengimani sifat-sifat Allah.

Dari ke uraian tujuan pembelajaran di atas, dapat peneliti analisis bahwa berdasarkan komponen-komponen dalam merumuskan tujuan, maka tujuan pembelajaran yang dibuat GAA.N, GAA.AF dan GAA.AB di atas telah memenuhi unsur-unsur dalam perumusan tujuan pembelajaran. Sedangkan tujuan pembelajaran GAA.DS belum sesuai dengan panduan penyusunan RPP yang dikeluarkan kementerian pendidikan dan kebudayaan, bahwa 
penyusunan tujuan pembelajaran menggunakan rumus $\mathrm{ABCD}$, dan dalam penulisanya $\mathrm{C}$ (Conditioning) biasanya terletak diawal.

Berdasarkan data di atas tujuan pembelajaran yang dibuat guru sebagian telah sesuai dengan rumusan dalam menentukan tujuan pembelajaran, serta telah memberikan gambaran proses pembelajaran, dan hanya satu Madrasah yang belum sesuai dari segi urutan penulisanya.

\section{Materi Pelajaran}

Materi pembelajaran, memuat fakta, konsep, prinsip, dan prosedur yang relevan, dan ditulis dalam bentuk butir-butir sesuai dengan rumusan indikator ketercapaian kompetensi. Materi pembelajaran berhubungan dengan tujuan yang ingin dicapai dalam suatu pembelajaran. Berdasarkan dokumentasi perangkat pembelajaran yang peneliti terima dari GAA.N, materi pelajaran yang ditulis dalam RPP tidak ditulis dalam bentuk butir-butir sesuai dengan rumusan indikator ketercapaian kompetensi, tapi materi pelajaran ditulis berdasarkan urutan fakta, konsep, prinsip dan prosedur.

Setelah peneliti konfirmasi kepada guru yang bersangkutan, GAA.N menjelaskan, “Untuk materi pelajaran yang kami masukkan dalam RPP, kami susun berdasarkan fakta, konsep, prinsip, dan prosedur pak. ya selama ini kita buat begitu pak". Sedangkan dalam RPP GAA.AF, guru menuliskan materi pelajaran tidak mengikuti aturan yang telah ditentukan. Materi pelajaran ditulis berdasarkan urutan fakta, konsep, prinsip dan prosedur dan tidak ditulis butirbutir sesuai indikator. Terkait materi pembelajaran, GAA.AF menjelaskan,"Materi ya kita masukkan poin-poinya saja pak. Untuk materi secara utuh kita menggunakan buku ajar, yang sudah disediakan madrasah".

Dari pernyataan diatas, setelah peneliti membandingkan dengan dokumen RPP yang peneliti terima, ada ketidak sinkronan antara pernyataan GAA.AF dengan dokumen RPP, karena dalam RPP guru tidak memasukkan materi berdasarkan poin-poin sesuai dengan indikator pembelajaran. Dalam RPP GAA.AB yang peneliti terima guru Guru menuliskan materi pelajaran tidak mengikuti aturan yang telah ditentukan. Materi pelajaran ditulis berdasarkan urutan fakta, konsep, prinsip dan prosedur dan tidak ditulis butir-butir sesuai indikator. Terkait materi pembelajaran, GAA.AB menjelaskan,"Untuk materi ajar hanya dimasukkan garis besarnya saja ke dalam RPP, nanti untuk penjelasanya kita sendiri yang menjelaskan".

Berdasarkan analisis peneliti terhadap RPP GAA.AB, ditemukan bahwa penulisan materi pembelajaran tidak sesuai dengan aturan yang dikeluarkan kemdikbud, karena materi ditulis berdasarkan bagian-bagian aspek pembelajaran bukan ditulis dalam bentuk butir-butir sesuai dengan rumusan indikator ketercapaian kompetensi. Dan untuk MTs Darussalam penulisan metrik telah sesuai dengan aturan.

\section{Metode Pembelajaran}

Metode pembelajaran digunakan oleh pendidik untuk mewujudkan suasana belajar dan proses pembelajaran agar peserta didik mencapai KD yang disesuaikan dengan karakteristik peserta didik dan KD yang akan dicapai. Membuat atau membangun metode pembelajaran yang inovatif sendiri ini bisa dilakukan dengan berbagai cara diantaranya mengakomodir karakteristik setiap diri siswa. Artinya mengukur daya kemampuan serap ilmu masing-masing siswa. Contohnya sebagian siswa ada yang berkemampuan dalam menyerap ilmu dengan menggunakan visual atau mengandalkan kemampuan penglihatan, auditory atau kemampuan mendengar, dan kinestetik. Dan hal tersebut harus di sesuaikan pula dengan upaya penyeimbang fungsi otak kiri dan otak kanan yang mengakibatkan proses renovasi mental, diantaranya membangun rasa percaya diri siswa. Proses kreatif dimaksudkan agar menciptakan kegiatan belajar yang beragam sehingga memenuhi berbagai tingkat kemampuan siswa. 
Sedangkan untuk menjadi menyenangkan adalah menciptakan suasana belajar-mengajar yang tidak membosankan, sehingga siswa memusatkan perhatiannya secara penuh pada belajar sehingga waktu tercurah secara komprehensif. Sedangkan dalam pemilihan metode pembelajaran ada yang harus dipertimbangkan, yakni keadaan murid yang mencakup pertimbangan tentang tingkat kecerdasan, tujuan yang hendak dicapai, alat-alat yang tersedia akan mempengaruhi pemilihan metode yang akan digunakan kemudian kemampuan pengajaran tentu menentukan, mencakup kemampuan fisik keahlian (Tafsir, 2003).

Menentukan metode pembelajaran yang tepat dalam proses pembelajaran, merupakan kunci keberhasilan guru dalam menyampaikan materi pelajaran kepada siswa. Dari hasil telaah RPP yang peneliti lakukan, terlihat bahwa dari ke empat RPP yang peneliti terima ada tiga RPP yang mempunyai kesamaan dalam menentukan metode pembelajaran, ketiga RPP tersebut yaitu RPP GAA.N, GAA.AF dan GAA.AB. Adapun metode yang digunakan adalah Pendekatan Scientific. Model Direct instruction dan Artikulasi, Metode Active Learning, Diskusi, Tanya Jawab, Role Play dan Demonstrasi. Sedangkan metode yang digunakan oleh GAA.DS tidak jauh berbeda dengan metode sebelumnya seperti Pendekatan scientific, model direct instruction dan model artikulasi (membuat dan mencari pasangan untuk mengetahui daya serap peserta didik).

Dari uraian di atas dapat peneliti simpulkan bahwa guru Akidah Akhlak dalam menentukan metode pembelajaran sudah menggunakan pendekatan scientific dalam pembelajaran, seperti mengamati, menanya, mengumpulkan informasi, mengasosiasi dan mengkomunikasikan, dengan pendekatan tersebut dapat membuat para siswa menjadi aktif dalam pembelajaran, dengan pendekatan scientific pembelajaran yang berlangsung akan menjadi lebih aktif, model dan metode yang digunakan sesuai dengan tujuan pembelajaran.

\section{Evaluasi/Penilaian}

Pada bagian evaluasi, telah dipaparkan secara rinci cara- cara penilaian yang akan dilaksanakan dalam proses pembelajaran. Dimulai dari penilaian dalam aspek sikap, pengetahuan, dan keterampilan. Kesemuanya sudah ada di RPP lengkap dengan instrumen penilaian masing-masing aspek. Dari hasil telaah RPP yang peneliti lakukan, semua RPP yang dibuat guru Akidah Akhlak telah membuat rencana pelaksanaan penilaian, dari masing-masing rencana penilaian akan peneliti jabarkan sebagai berikut.

Untuk rencana penilaian di RPP dijabarkan bahwa GAA.N merencanakan penilaian pengetahuan dengan tes tulis. Lembar penilaian ranah pengetahuan telah tertera di RPP. Lembar penilaian tersebut berisikan 20 butir soal pilihan ganda dan 5 butir soal essay serta skor nilainya. Kemudian lembar penilaian ranah sikap dengan tehnik Observasi lengkap dengan rubriknya. Dan untuk keterampilan sudah tertera kolom-kolom yang nantinya digunakan untuk menilai keterampilan dengan tehnik unjuk kerja (mempresentasikan hasil diskusi siswa).

Selanjutnya dalam rencana penilaian GAA.AF dijabarkan bahwa, GAA.AF merencanakan penilaian pengetahuan dengan tes tulis, dalam dokumen RPP yang peneliti terima, sudah disiapkan soal-soal uraian, lengkap dengan rubrik penilaian beserta skornya. Kemudian untuk penilaian ranah sikap GAA.AF merencanakan dengan tehnik Observasi, di dalam dokumen RPP juga guru telah menyiapkan lembar pengamatan beserta rubrik penilain. Dan untuk penilaian keterampilan guru merencanakan penilaian dengan Unjuk Kerja, seperti keterampilan bertanya, keterampilan dalam berbicara, serta guru telah menyiapkan rubrik yang akan digunakan untuk menilai keterampilan.

Sedangkan rencana penilaian dalam RPP GAA.AB dijabarkan bahwa GAA.AB merencanakan melakukan penilaian pengetahuan dengan tes tulis pilihan ganda. Lembar evaluasi aspek pengetahuan telah tertera di RPP. Lembar penilaian tersebut berisikan 20 butir soal pilihan ganda lengkap dengan kunci jawaban serta 5 butir soal Essay dan rubrik penilaian. 
Kemudian ada lembar penilaian aspek sikap, penilaian menggunakan tehnik Observasi, pada RPP juga sudah tersedia rubrik pengamatan sikap. Dan untuk penilaian keterampilan dalam RPP sudah tertera aspek-aspek penilaian serta rubrik yang nantinya digunakan untuk menilai keterampilan dengan tehnik unjuk kerja (mempresentasikan hasil diskusi siswa).

Kemudian dalam rencana penilaian, GAA.DS merencanakan penilaian pengetahuan dengan tes tulis. Lembar penilaian ranah pengetahuan telah tertera di RPP. Lembar penilaian tersebut berisikan 10 butir soal lengkap dengan kunci jawaban. Kemudian juga ada lembar penilaian ranah sikap dengan tehnik Observasi. Dan untuk keterampilan sudah tertera kolomkolom yang nantinya digunakan untuk menilai keterampilan dengan tehnik unjuk kerja (mempresentasikan hasil diskusi siswa).

Dari paparan data tentang rencana pelaksanaan penilaian di atas dapat peneliti simpulkan bahwa semua guru telah menyiapkan rencana penilaian sesuai dengan komponen-komponen yang harus dinilai, namun berdasarkan analisis peneliti dari keempat RPP di atas hanya satu RPP yang memuat kunci jawaban pada rencana penilaiannya yaitu RPP GAA.DS, sedangkan RPP GAA.N, GAA.AF dan GAA.AB tidak membuat kunci jawaban dalam rencana penilaianya.

Dari keempat RPP diatas, berdasarkan telaah RPP yang peneliti lakukan, dapat peneliti simpulkan bahwa dalam penyusunan RPP masih terdapat beberapa bagian yang belum sesuai dengan permendikbud no 22 tahun 2016 tentang Standar Proses Pendidikan Dasar dan Menengah, seperti pada bagian penulisan materi. Pada RPP GAA.N, GAA.AF dan GAA.AB materi pelajaran tidak ditulis dalam bentuk butir-butir sesuai dengan rumusan indikator ketercapaian kompetensi, tapi materi pelajaran ditulis berdasarkan urutan fakta, konsep, prinsip dan prosedur. Selanjutnya pada bagian rencana penilaian pada RPP GAA.N, GAA.AF guru tidak membuat kunci jawaban dari soal-soal yang dibuat.

Kemudian secara keseluruhan penulisan RPP masih belum mengikuti aturan, diantaranya urutan dalam penulisan RPP tidak sesuai dengan panduan penulisan RPP yang dikeluarkan oleh Kemdikbud. Dalam penduan penulisan RPP disebutkan bahwa urutan komponen RPP sebagai berikut, 1) identitas sekolah, 2) identitas mata pelajaran, 3) kelas/semester, 4) materi pokok, 5) alokasi waktu, 6) tujuan pembelajaran, 7) kompetensi dasar dan indikator, 8) materi pembelajaran, 9) metode pembelajaran, 10) media pembelajaran, 11) sumber belajar, 12) langkah-langkah pembelajaran, dan 13) penilaian hasil pembelajaran. Berdasarkan dokumen RPP yang peneliti terima semua RPP tidak mengikuti urutan komponen RPP di atas, guru Akidah Akhlak membuat urutan sebagai berikut; 1) identitas sekolah, 2) identitas mata pelajaran, 3) kelas/semester, 4) materi pokok, 5) alokasi waktu, 6) tujuan pembelajaran, 7) kompetensi dasar dan indikator, 8) materi pembelajaran, 9) sumber belajar, 10) langkahlangkah pembelajaran, 11) metode pembelajaran, 12) media pembelajaran, dan 13) penilaian hasil pembelajaran.

Ketika menganalisa RPP, peneliti menemukan beberapa kejanggalan, yaitu rata-rata dari keempat RPP yang peneliti terima mempunyai karakter dan pola yang sama, kesalahan pada poin-poin yang sama juga, berdasarkan analisa tersebut peneliti menduga bahwa RPP yang dibuat guru Akidah Akhlak berasal dari sumber yang sama.

Untuk mencari tahu tentang kejanggalan tersebut peneliti menanyakan langsung kepada guru Akidah Akhlak. Kemudian hasil wawancara peneliti dengan guru Akidah Akhlak mereka dengan jujur mengatakan bahwa, sebenarnya perangkat pembelajaran yang mereka buat bukan merupakan karya mereka sendiri melainkan hasil download dari internet. 


\section{Analisis Penyebab Munculnya Masalah Dalam Implementasi Kurikulum 2013 Pada Pembelajaran Akidah Akhlak di MTs Kota Prabumulih}

Berdasarkan paparan data tentang problematika implementasi kurikulum 2013 di MTs Kota Prabumulih di atas, berdasarkan analisis peneliti, problematika di masing-masing madrasah tidak jauh berbeda. Pertama permasalahan pada tahap perencanaan, dari keempat madrasah yang peneliti teliti, permasalahan utama adalah pembuatan RPP yang tidak sesuai dengan panduan pembuatan RPP yang dikeluarkan oleh Kemdikbud, sebagian besar kesalahan pada penulisan materi dan urutan dalam penulisan RPP. Kemudian kesamaan problematika diatas karena dilatar belakangi bahwa RPP yang dimiliki guru Akidah Akhlak tersebut bukan merupakan karya yang dibuat oleh masing-masing guru, melainkan bersumber pada sumber yang sama yaitu hasil download dari internet.

Permasalahan diatas atas tentu ada faktor penyebabnya, faktor-faktor tersebut menurut peneliti adalah Pertama terletak pada lemahnya semangat dan kesungguhan guru dalam menyiapkan perangkat pembelajaran, Kedua pemahaman guru terhadap konsep pembuatan RPP yang masih kurang sehingga guru masih kesulitan untuk membuat RPP secara mandiri, hal ini sesuai dengan pernyataan GAA.N "Untuk membuat RPP sendiri masih terasa sulit pak. karena banyak bahan yang harus disiapkan". Hal senada juga disampaikan GAA.AF "Untuk membuat sendiri RPP secara keseluruhan sih, sebenarnya 'belum terlalu paham dengan K13 sendiri, kita masih mengalami kesulitan". Kemudian GAA.AB juga menjelaskan , "Kalau membuat RPP sendirikan harus menganalisis sendiri semua komponennya dek, bagi saya analisisnya masih membingungkan, kemudian lembaran-lembaranya sangat banyak dan rumit, belum lagi perangkat perangkat yang lain, bagi kami yang sudah tua ini sangat melelahkan ditambah lagi waktu yang tersedia terbatas". Selanjutnya GAA.DS menjelaskan, "Masih kurang sosialisasi, contoh pembuatan RPP hanya dijelaskan secara teori, itupun kami dapat dari guru yang ikut pelatihan, tidak ada contoh yang konkrit, faktor lain sarana kita belum mendukung, seperti alat multimedia dll, ditambah lagi dengan adanya beberapa revisi K13, sehingga pemahaman yang kami terima tidak utuh".

Pernyataan-pernyatan guru di atas merupakan bukti bahwa guru belum mampu untuk membuat RPP secara mandiri. Ketiga tentu yang menjadi faktor juga adalah perhatian madrasah kepada guru masih sangat kurang, RPP yang dibuat guru harus diketahui oleh kepala madrasah yang dibuktikan dengan tanda tangan kepala madrasah, dengan demikian seharusnya seorang kepala sekolah bisa menilai RPP yang dibuat guru tentu melalui jajaran yang yang ada untuk selanjutnya jika memanng belum memenuhi standar harus ada perbaikan dan diadakan pelatihan bagi guru.

Kedua Problematika pada tahap pelaksanaan, berdasarkan hasil analisis peneliti problem utama adalah kurangnya penguasaan guru terhadap langkah-langkah dalam proses pembelajaran, baik dalam tahap awal, inti dan penutup. Hal ini terlihat dengan banyaknya langkah-langkah dalam pembelajaran yang tidak dilakukan guru, selanjutnya penerapan metode saintifik belum dapat diterapkan secara utuh kemudian pembagian waktu pada tiap-tiap langkah pembelajaran belum maksimal, karena dari keempat Madrasah yang peneliti observasi guru Akidah Akhlak mengakhiri pembelajaran secara mendadak.

Dari permasalahan pelaksanaan diatas menurut analisis peneliti yang menjadi faktor adalah: 1) kemampuan guru masih kurang, guru belum mampu menciptakan pembelajaran yang menumbuhkan kreatifitas siswa, 2) Guru tidak menjadikan RPP sebagai pedoman dalam mengajar, ketika guru tidak menjadikan RPP sebagai pedoman dalam mengajar tentu pembelajaran akan berlangsung dengan tidak terarah, hal ini terlihat dengan banyaknya langkah-langkah dalam pembelajaran yang tidak dilaksanakan guru, 3) Guru tidak menguasai alur pembelajaran kurikulum 2013, dengan guru tidak menguasai alur pembelajaran akhirnya 
guru mengajar hanya mengikuti situasi saja, guru tidak menciptakan situasi belajar yang baik dan menyenangkan.

Ketiga problematika pada tahap penilaian, pelaksanaan penilaian merupakan rangkaian yang tidak dapat dipisahkan dari proses pembelajaran. Berdasarkan hasil analisis peneliti dari keempat guru Akidah Akhlak sebagian besar guru masih merasa sulit dalam melaksanakan penilaian secara baik karena guru menganggap penilaian autentik rumit. Berdasarkan analisis peneliti yang menjadi faktor adalah kemampuan guru dan motivasi guru yang masih sangat kurang. Dari uraian analisis faktor problematika implementasi kurikulum 2013 diatas dapat peneliti simpulkan bahwa yang menjadi faktor secara umum dari problematika implementasi kurikulum 2013 di atas adalah: Kurangnya motivasi guru dalam implementasi kurikulum 2013, Pemahaman guru tentang konsep kurikulum 2013 masih kurang, Maindset guru tentang kurikulum 2013 belum sempurna, sehingga proses pembelajaran sebagian masih seperti kurikulum KTSP, Semangat dan etos kerja guru yang rendah, guru cenderung malas untuk mengevaluasi pembelajaran dan memperbaikinya.

Dari seluruh faktor di atas, menurut analisis peneliti yang menjadi faktor utama terletak pada pribadi guru, Implementasi kurikulum 2013 tidak dapat terlaksana dengan baik tanpa guru yang mempunyai semangat yang tinggi, kemauan yang keras dalam melaksanakan kurikulum 2013.

\section{Upaya-upaya yang dilakukan guru MTs Negeri Prabumulih dalam mengatasi problematika Implementasi Kurikulum 2013 pada pembelajaran Akidah Akhlak}

Dari berbagai macam problematika dalam Implementasi Kurikulum 2013 di MTs Kota Prabumulih serta faktor-faktor yang melatar belakanginya, berdasarkan hasil penelitian dan wawancara peneliti kepada masing-masing guru Akidah Akhlak maka dapat peneliti simpulkan bahwa 1) Guru MTs Negeri Prabumulih Upaya-upaya yang dilakukan GAA.N diantaranya: Mencari pengetahuan tentang konsep kurikulum 2013 dari internet. Bertanya dengan kawan sejawat dan guru yang lebih senior, tentang pembuatan rencana pembelajaran. Sedangkan pada bagian proses dan penilaian, peneliti belum menemukan adanya upaya yang dilakukan guru, untuk mengatasi problematika tersebut. 2) Guru MTs Al Furqon Selama peneliti berada di MTs Al Furqon dari hasil observasi maupun hasil wawancara, peneliti belum menemukan usahausaha yang dilakukan GAA.AF dalam mengatasi problematika implementasi kurikulum 2013. 3) Guru MTs Amal Bakti Dari hasil penelitian peneliti selama berada di MTs Amal Bakti, adapun upaya yang telah dilakukan guru untuk mengatasi problematika implementasi kurikulum 2013 yaitu: Banyak latihan dalam implementasi kurikulum 2013, baik dalam tahap pembuatan rencana pembelajaran, pelaksanaan proses dan evaluasi, Aktif mengikuti Musyawarah Guru Mata Pelajaran bersama madrasah Induk, Aktif mengikuti pelatihanpelatihan tentang kurikulum 2013. 4) Guru MTs Darussalam Berdasarkan hasil wawancara peneliti dengan GAA.AB, upaya yang telah dilakukan oleh guru diantara: Berusaha untuk mencari tahu tentang perkembangan kurikulum 2013 secara mandiri baik dari internet maupun bertanya kepada guru yang lebih senior. Berperan aktif dalam kegiatan MGMP dan menggali pengalaman dari guru-guru sekolah lain.

Sedangkan menurut penilaian peneliti, upaya atau usaha yang mestinya dilakukan guru dalam dalam mengatasi problematika Implementasi Kurikulum 2013 pada pembelajaran Akidah Akhlak yaitu membuat atau membangun metode pembelajaran yang inovatif dan membuat pembelajaran yang menyenangkan Learning in fun tersebut sudah dapat membawa perubahan. Terlihat dari sikap siswa yang mulai ada perhatian, mulai ada yang bertanya dan rasa ingin tahu terhadap apa yang disampaikan guru saat kegiatan belajar mengajar berlangsung. Dengan demikian kurikulum 2013 membuat siswa yang aktif dalam pembelajaran di kelas dan guru hanya sebagai pendorong dan penyemangat siswa dalam pembelajaran. Dan 
menambah wawasan lagi dalam mengikuti pelatihan-pelatihan kurikulum 2013 untuk mengetahui bagaimana cara membuat RPP dan penilaian yang lebih mengedepankan deskripsi siswa. Tidak hanya pengetahuan kognitif saja yang dinilai namun semua komponen dari afektif dan psikomotor siswa juga ikut dinilai. Dengan adanya perencanaan yang baik dan terstruktur maka tujuan pembelajaran akan berjalan efektif dan efisien.

\section{KESIMPULAN}

Problematika implementasi kurikulum 2013 dibagi menjadi tiga tahapan, mulai dari tahapan perencanaan, tahap pelaksanaan dan tahap evaluasi. dari ketiga tahapan tersebut peneliti menemukan beberapa problematika dalam implementasinya, yaitu: Pertama Problematika tahap perencanaan, seperti; 1) Penulisan materi tidak sesuai dengan panduan, 2) Urutan dalam pembuatan RPP tidak mengikuti pedoman penulisan RPP, 3) Rata-rata guru MTs Prabumulih RPP hasil download (copy) dan hanya diganti identitasnya saja. Kedua Problematika tahap pelaksanaan, diantaranya: 1) Pada kegiatan Pendahuluan, guru tidak memberikan motivasi belajar kepada peserta didik, guru tidak menyampaikan tujuan pembelajaran, guru tidak menyampaikan cakupan materi dan uraian kegiatan. 2) Kegiatan Inti, dalam kegiatan inti guru tidak menerapkan metode pembelajaran sesuai dengan RPP, proses pembelajaran masih didominasi oleh guru, guru hanya terfokus pada kegiatan inti, guru tidak menggunakan RPP sebagai acuan dalam proses pembelajaran, serta pendekatan ilmiah (scientific) belum terlihat secara keseluruhan saat proses pembelajaran. Secara umum pembelajaran belum sepenuhnya mencerminkan implementasi dari kurikulum 2013. 3) Kegiatan Penutup, seperti guru tidak melakukan kegiatan refleksi, guru tidak memberikan umpan balik terhadap proses pembelajaran, guru tidak menginformasikan rencana kegiatan pembelajaran untuk pertemuan berikutnya. Ketiga Problematika tahap evaluasi; dalam evaluasi pembelajaran ada tiga aspek yang dinilai, mulai dari aspek sikap, aspek pengetahuan dan aspek keterampilan. Dari ketiga aspek tersebut aspek sikap dan keterampilan belum dapat terlaksana dengan baik.

Dari setiap problem dalam implementasi kurikulum 2013 mulai dari tahap perencanaan, tahap pelaksanaan dan tahap evaluasi, secara umum faktor-faktor tersebut adalah; Pertama Kurangnya motivasi guru dalam implementasi kurikulum 2013, Kedua masih kurangnya pemahaman guru tentang konsep kurikulum 2013 dari semua aspek, Ketiga Maindset guru tentang kurikulum 2013 belum sempurna. Keempat Semangat dan etos kerja guru yang rendah, guru cenderung malas untuk mengevaluasi proses pembelajaran dan memperbaikinya.

Dari berbagai macam problematika dalam Implementasi Kurikulum 2013 di MTs Prabumulih, berdasarkan hasil penelitian dapat peneliti simpulkan bahwa upaya-upaya yang sudah dilakukan guru akidah akhlak seperti; Pertama guru mencari informasi tentang konsep kurikulum 2013 secara mandiri, Kedua berperan aktif dalam kegiatan MGMP, Ketiga bertanya dengan guru yang lebih senior dalam implementasi kurikulum 2013. Dari usaha-usaha yang telah dilakukan guru Akidah Akhlak di atas, sudah terlihat ada usaha guru dalam mengatasi problematika yang ada walau belum signifikan.

\section{DAFTAR PUSTAKA}

Ahmad, S. (2014). Problematika Kurikulum 2013 dan Kepemimpinan Instruksional Kepala Sekolah. Jurnal Pencerahan, 8 (2), 98-108.

Arifin, Z. (2017). Konsep dan Model Pengembangan Kurikulum. Bandung: Rosda.

Kemendikbud .(2016). Permendikbud Nomor 22 Tahun 2016 Tentang Standar Proses Pendidikan Dan Menengah. Jakarta: Kemendikbud.

Kunandar. (2007). Guru Profesional Implementasi Kurikulum Tingkat Satuan Pendidikan (KTSP) dan Sukses dalam Sertifikat Guru. Jakarta: Raja Grafindo Persada. 
Mulyasa, E. (2014). Pengembangan dan Implementasi Kurikulum 2013. Bandung: PT. Remaja Rosdakarya.

Poerwati, L. E. (2013). Panduan Memahami Kurikulum 2013. Jakarta: PT. Prestasi Pustakarya. Sugiyono. (2014). Metode Penelitian Pendidikan Pendekatan Kuantitatif, Kualitatif, dan R\&D. Bandung: Alfabeta.

Tafsir, A. (2003). Metodologi Pengajaran Agama Islam. Bandung: PT. Rosda Karya. Uno, B. H. (2006). Perencanaan Pembelajaran. Jakarta: PT Bumi Aksara.

Yani, A. (2013). Mindset Kurikulum 2013. Bandung: Alfabeta. 